\title{
Cognitive linguistic analyses of the phraseological units in modern linguistics
}

\author{
Kalamkas Kalybayeva - Sagira Odanova - Altynai Tymbolova - Shattyk \\ Erchozhina - Gulbagiza Musayeva
}

DOI: $10.18355 /$ XL.2020.13.02.18

\begin{abstract}
In our research, we set out to show the specifics of the implementation of the sign of constructive conditionality in the field of phraseology, to establish the syntactic constructions necessary for the semantics of phraseological units, characterized by the constructive conditionality of their functioning, to show the determinism of the structure that defines the use of phraseological units in speech, the grammatical structure and the lexical-grammatical composition of verbal complex-prototype of the phraseological unit. Phraseological units that realize their values under the condition of a strictly defined structure are characterized by a sign of constructive conditioning. Such units are widely represented in modern English and, along with other types of phraseological units, are part of the English phraseological foundation. They are not able to independently represent what is indicated by means of the values assigned to them, irrespective of the mandatory actualizing effect on these values from the side of the verbal sign.
\end{abstract}

Key words: cognitive, linguistic, analyses, phraseological, phenomena, modern

\section{Introduction}

It is well known that phraseological units are characterized by complex, nonelementary semantics that also integrate pragmatically oriented information since the most diverse types of information are interwoven in phraseological units: description, reflecting the denotative core of meaning; the speaker's assessment of the situation described by the phraseological unit; information about the emotional-evaluative attitude of the speaker to the signified, motivated by the associative-figurative representation that is associated with the internal form of the phraseological unit and phraseological picture of the world; functional and stylistic significance.

All these types of information are characterized by syncretism, they form an indissoluble unity and at the same time reflect the structure of the meaning according to the types of information transmitted, and can be isolated in the structure of the meaning of phraseological units and highlighted through semantic oppositions of phraseological units in the corpus of the whole language.

However, the dialectic of describing phraseological units on a communicativefunctional basis lies precisely in determining how to divide this unity into parameters that can be reconnected in the description without losing the integral meaning of idioms as a language phenomenon.

To disassemble the object of analysis of phraseological units, while maintaining their integrity during synthesis, is a requirement that phraseological parameters (types of information) must meet as the minimum units for describing phraseological units.

The parameterization of the value of phraseological units has great explanatory power, reflecting the essential properties of the object of analysis and allowing it to be applied to the creation of highly informative phraseological dictionaries of the language.

A significant place in the semantic structure of phraseological units is occupied by pragmatic components. Under pragmatic information, we mean a combination of diverse relationships, assessments (social, ideological, aesthetic, moral, emotive, etc.) associated with the functioning of phraseological units. 
The subject of pragmatics at the level of phraseology are primarily such components of the semantics of phraseological units as evaluative and emotive. However, the pragmatics of phraseological units can be understood more broadly as the sum of "connotations (social, cultural, ethical, historical, emotive, expressive, evaluative, associative), as well as the specifics of semantics (features of a denotative orientation) are all numerous and diverse elements "(Sklyarevskaya, 1993), accompanying the phraseological meaning (and partly included in its structure)," which speech act carry information about the intentions of the speaker of the speech situation, the status of interlocutors on the assessment of the subject of the speech, etc. " (Sklyarevskaya,1993).

In general, pragmatics is determined by the need to choose linguistic means (in our case, phraseological units) speaking to express a wide variety of intentions. Thus, pragmatics can be characterized in the most general form as the attitude of speakers to the signs of the language (Morris, 1971). As we will see later, pragmatics has no clear contours; it includes a complex of issues related to the speaking subject, addressee, their interaction in communication, and the situation of communication.

Pragmatic information was revealed and described mainly at the semantic, stylistic, grammatical levels. As for phraseology, there is a very small number of works in which pragmatics was the direct subject of description (Telia 1996).

There are still many questions regarding the pragmatics of phraseological units that have not yet been resolved. Many components of pragmatic information contained in phraseological units were not identified, the mechanism of interaction of pragmatic elements with other components of the semantics of phraseological units, in particular, denotation, motivational and functional-style components, was not described, types of implementation of pragmatic information in phraseological units (explicit and implicit) were not clarified identification form); it is also necessary to clarify how cultural and national features of phraseological units influence the formation of pragmatic information, etc.

The world of phraseology of the modern English language is large and diverse, and every aspect of its research, of course, deserves due attention.

A lot of researchers have been written about phraseology, and the interest of researchers in this area of the language does not wane. The very fact of the presence in the language, in addition to words of whole verbal complexes, which are sometimes identical with the word, and more often are a unique linguistic phenomenon, characterized by vivid expressiveness, imagery and emotionality, serves as an occasion for us to study this particular section of linguistics.

A. I. Alekhina notes that "the study of phraseology as a systemic phenomenon, which has its own units of research and is characterized by its unique organization of these units, began in the recent past and continues to the present" (Alekhina, 1982).

The question of phraseology as a linguistic discipline was posed by such an outstanding linguist as professor E.D. Polivanov, who believed that " there is a need for a special department that would be commensurate with the syntax, but at the same time had in mind not general types, but individual meanings of the data of individual phrases, similar to the fact that vocabulary deals with individual (lexical) meanings of individual words "(Polivanov, 1991).

This part of linguistics Polivanov named phraseology. He foresaw that phraseology would take a separate and stable position (like phonetics, morphology, etc.) in the linguistic literature of the future, "when in the sequential formulation of various problems our science will be free from random gaps" (Polivanov, 1968).

Summarizing a wide range of views on phraseology, the following can be noted. In modern linguistics, two areas of research are clearly outlined. The first direction of the starting point is the recognition that the phraseological unit is such a unit of language that consists of words, that is, by its nature - a phrase. At the same time, some

XLinguae, Volume 13 Issue 2, April 2020, ISSN 1337-8384, ISSN 2453-711X 
scientists express the idea that the object of phraseology is all concrete phrases that are really possible in a given language, regardless of the qualitative differences between them. So, for example, M.M. Kopylenko and Z.D. Popov say that: "Phraseology covers all ... combinations of lexemes existing in a given language, including the so-called" free "phrases" (Kopylenko, Popova, 1989). In their understanding, phraseology is "a special section of linguistics that studies the laws of compatibility of lexemes."

On the other hand, the object of phraseology within the boundaries of this direction is recognized only by certain categories and groups of phrases that stand out from all the possibilities in speech with special originality. Depending on what features are considered when selecting such phrases, the composition of such units in the language is determined. Only these "special" phrases can be called phraseological units. Despite the conventionality of concepts and the related distinction, it is usually said that phraseology can be represented:

a) as a phraseology of a language in the "broad" sense of the word, which includes phrases that are completely rethought and phrases in which there are unreasoned component words. An example of such a "broad" understanding of the volume and composition of phraseology is the point of view of V.L. Arkhangelsky (1964) and others;

b) as a phraseology in the "narrow" sense of the word, which includes only phrases reinterpreted to the end. Among the works reflecting such an understanding of the volume and composition of phraseology include, for example, articles by Zhukova (2006).

In both cases, the verbal nature of phraseology, as well as the lexical nature of its components, is not called into question by scientists. Phraseology is recommended to be considered as a contamination of the features of a word and a phrase; the homonymy of phraseology and its correlation in terms of phrase structure is emphasized.

At the current stage of the development of phraseology, the researchers are particularly interested in developing theoretical directions that will take a fresh look at the rich phraseological material accumulated over the centuries and subject it to more thorough analysis in the light of new linguistic trends, especially such as cognitive linguistics and the theory of discourse.

One of the most important in modern linguistics is the functional direction. With a functional approach, the study of language processes is carried out inextricably linked with the needs of the communicative activity and involves the consideration of the human factor.

According to V. N. Telia, " the nature of phraseological units makes it necessary to study them within the framework of the anthropological paradigm that is emerging in the sciences of the humanitarian cycle. The human factor in the language of the dead language factor in man moves into the focus of linguistic studies" (Telia, 1996).

The main function of a language that is directly related to a person is considered cognitive. Cognitiveness underlies the formation of a conceptual picture of the world and reflects the process of perception and understanding of reality, which is carried out in concepts that are typical for a given language.

The cognitive approach to the study of the phraseological system of the language allows us to present phraseology in a new perspective, refracting it through the prism of thinking and types of knowledge, and also to see new aspects of the relationship of phraseology with grammar and vocabulary.

The following aspects are distinguished in the composition: significative, denotative, and connotative (Kunin, 1996).

I. I. Chernysheva notes the peculiarities of phraseological semantics that distinguish it from the lexical semantics: "If you represent the meaning of secondary education signs in the form of a set of semantic components, then in the word and in 
phraseological units as denotative, denotative- connotative and connotative components will be present" (Chernysheva, 1999).

However, the way of education and the material embodiment of connotation in a word and phraseologism are not the same. If, in a word, a semantic shift is created as a result of a change in denotation, then in phraseology this is a complete metaphorizing of a variable phrase or partial, depending on the type of phraseology.

The fact that in phraseologism the semantic shift affects the phrase (phraseological unity) or predicative combinations (phraseological expressions) creates a figurative motivation of meaning, phraseological image, which forms the semantics of a broad plan, with the ability to situational concretization in the text.

The connotative component of the meaning of phraseology, in contrast to the similar component of the lexical unit of secondary education, has the potential to increase the expressive potential through modification of the component composition. It is with this that the specificity of the expression of connotation through separately formed formations is connected.

The denotative component of meaning is understood as the part of the sign reflecting in generalized form objects and phenomena of extralinguistic reality. The denotative component is basically a concept that characterizes an extralinguistic object (Popova, Sternin, 2007).

The high significance of the connotative aspect in phraseology is explained by the two-pronged semantic structure of phraseological units built on figurative rethinking. Imagery contributes to the expressiveness and vivid emotionality of phraseological turns, creates objective prerequisites for expressing a diverse range of assessments in relation to the objects of reality he calls, it becomes one of the main incentives for the formation of the connotative component of their semantics. Therefore, "exploring the phraseological image as one of the sources of the rich connotation of phraseological units, we, first of all, reveal the specificity of the connotative component of the meaning of phraseological units - the main component of phraseological semantics" (Alekseeva, 1998). Many researchers argue that there is still no generally accepted understanding of connotation, and its composition and structure have not been adequately studied (Telia, 1996). The opinions of linguists on the question of what place the connotation occupies in the structure of the meaning of phraseological units differ. Often, the connotation is considered additional content that is "superimposed" on the significative and denotative components of meaning. However, this point of view does not consider the unity of the rational and the emotional in human knowledge. The most popular in modern linguistics, is the opinion that the connotative macro component, along with the significative and denotative components and intertwined with them. A. B. Kunin believes that the connotative aspect is "the stylistic coloring of the phraseological units, their emotionally expressive side, that is, the attitude of the native speaker to extralinguistic entities, or the increase in the effectiveness of linguistic influence devoid of an evaluative element" (Kunin, 1970). A.F. Artyomova assigns a leading role to the connotative aspect in the semantic structure of phraseological units since it is the connotation that largely determines the informative value of phraseological units (Artyomova, 1991). Understanding the connotation of the complex of all signals aimed at the emotional impact on the recipient, the researcher states: "The connotation is a macro component of the semantic structure that absorbs all the information - stylistic, evaluative and emotional, which together create content that is traditionally correlated with the concept of expressivity. V. N. Telia understands by connotation "any pragmatically oriented component of the plan of the content of linguistic entities (morphemes, words, phraseologisms and text fragments), which supplements their denotative and grammatical content on the basis of information correlated with pragmatic factors of various kinds" (Telia, 1996).

XLinguae, Volume 13 Issue 2, April 2020, ISSN 1337-8384, ISSN 2453-711X 
In determining the essence of connotation, V. N. Telia notes the importance of associative-background, that is, empirical, cultural-historical, worldview, etc., knowledge of those who speak this language about the properties or manifestations of the indicated reality or situation. Idioms are not created every time anew; they are extracted from the memory of a native speaker in a finished form and reproduced as something whole and indivisible.

If we talk about the connotative aspect of phraseological units, then we can distinguish the following components that give phraseological units semantic completeness: evaluative, emotive, expressive, and functional-stylistic.

The connotation is included in the semantics of phraseological units, usually or occasionally. Thanks to it, phraseological units acquire expressiveness and make the language vibrant and expressive.

The connotation of phraseological units is based on the principle of language saving. It does not formally express the speaker's intention to produce a certain effect on the listener. The attitude of the addressee and the addressee to the object from the world "real" is based on some knowledge about the world "real", on the sensory perception of objects from this world. The totality of all information about this relationship is a connotation.

The connotative component, called in modern studies "incremental subtlety", "semantic complementarity", "new meaning", "increment of meaning", is created by an internal living form that provides a figuratively associative perception of the situation (Kabanova, 2011).

A study of the structural and semantic properties of phraseological units, characterized by a sign of constructive conditionality, allows us to state some general points.

In our study, we made a general acquaintance with the formulation of the problem of studying linguistic units characterized by a sign of constructive conditionality in English studies, showed the specifics of a structurally determined meaning based on the lexical meaning of a word, identified the factors that influence the formation of construction that replenishes the meaning of phraseology.

We have developed a new interpretation of the nature of the constructive conditionality of phraseological units that determine this phenomenon of determination. The analysis of the internal form of phraseologism provided informative, significant data for identifying the specifics of constructive conditioning in the field of phraseology, and made it possible to combine the available data in a new and more adequate way. Having analyzed the phraseological image and its role in the breadth of compatibility of the units under consideration, it was possible to show that constructive conditionality in the field of phraseology depends not only on the specifics of the semantics of phraseological units but also on the specifics of phraseological images motivating semantics.

The phraseological image clearly shows the action, phenomenon, or property that becomes a motivational attribute that forms a phraseological meaning. The phraseological image is formed by those elements of the linguistic structure that are directly involved in the implementation of the meaning of phraseological units, i.e. components.

In this regard, the analysis of verbal complexes-prototypes of phraseological units is of particular relevance. In our study, we focused on the analysis of phraseological units, which, by the nature of the structure of verbal complexes-prototypes, are represented by the following types: phraseological units having the structure of an unpredictive verb combination of words, and verb type phraseological units having the structure of a predicative combination of words.

Verbal complexes of the analyzed phraseological units are either a free combination of words or not free, but grammatically, all these combinations are built on the syntactic models existing in modern English. In our research, we systematized all 
structural models of verbal complexes-prototypes of phraseological turns of interest to us.

The units selected for analysis are characterized by different types of model lengths. Verbal complexes, represented by two components, are implemented in syntactic models of verb phrases in which the verb controls nouns in the forms of the genitive, dative, accusative, instrumental cases or is connected with an adverb; as well as in the syntactic model of an unallocated two-part sentence.

Verbal complexes represented by three components implemented in syntactic models of verbal phrases are formed by combining a verb with a prepositional case form, some phraseological phrases include two nouns in different indirect cases. Some prototype verbal complexes in their structure have an adjective or pronoun or numeral consistent with the noun. Several verbal complexes include, as a third member, a particle not in the verb, some phraseological units include a pronoun with a preposition.

Phraseological units are also three-component, the verbal complexes-prototypes of which are represented by negative uncommon two-part sentences, as well as two-part wide sentences, which have one secondary term used without an excuse. Threecomponent complexes are distinguished among units that are formally grammatically correlated with one-component sentences: definitely personal, impersonal, infinitive.

Four-component verbal complexes-prototypes of phraseological units are represented by syntactic models of verbal phrases and common two-part and one-part sentences. The former are various combinations of verbs, nouns with and without prepositions, adjectives, pronouns, consistent with these nouns; Structural models of a small number of phraseological units may contain particles and unions.

The second, correlative with the widespread two-part sentences, consisting of a predicative core and one minor member in the prepositional case form; still others are represented by individual models of impersonal, definitely personal, indefinitely personal and infinitive sentences.

Among the phraseological units of the analyzed type, several five- and six-component phraseological units are identified that are correlated with non-predicative combinations. Verbal complexes of predicative phraseological units consist of five components in cases where the predicate is used with a negative particle, and the secondary term is in the prepositional case form, or in cases where the complex form a predicate and two minor terms in the prepositional case forms.

Among the units analyzed, phraseological units were found that are formally grammatically correlated with complex sentences, the main part of which are the components of phraseological units to show and not know: show where the crayfish hibernate (to whom), do not know where to go (what), etc.

In research, we determined the structural typology of verbal complexes-prototypes of the analyzed phraseological units, without considering the semantics of structuralsemantic constructions supplementing them. The phraseological units under consideration, in order to realize their meanings, need contextual support of structurally related words.

Any object necessary to realize the meaning of phraseology, regardless of the case form and the presence/absence of an excuse, is mandatory. It serves to manifest the self-sufficiency of phraseological units. Between the phraseological unit and the object, the necessary semantic and grammatical connection is established.

This element of the sentence, which is a characteristic attribute of the design of its structure and plays a paramount role in revealing the content of phraseological units, we have designated the term structural and semantic supplement of phraseological units. Therefore, the further part of the research is devoted to the analysis of constructions, which include phraseological units of the considered structure and structural-semantic substitutes, which play the role of direct or indirect prepositional

XLinguae, Volume 13 Issue 2, April 2020, ISSN 1337-8384, ISSN 2453-711X 
and unproblematic additions. In identifying the specifics of the structural conditionality of phraseological units, we relied on the role of the internal form in the organization of structural-semantic constructions replenishing phraseological units. Revealing the connection between the internal form and the form of the structuralsemantic supplement of phraseological units has allowed us to explain the essence of the realization of the sign of constructive conditioning.

For the realization of the sign of constructive conditioning in the field of phraseology, the recognition of the verbal nature of the components of the phraseological units under consideration is of great importance, as well as the fact that the phraseological unit has integral semantics and acts as a whole with respect to the managed word. These circumstances are directly related to the essence of the phenomenon of constructive conditioning.

These are the structural and semantic typologies of phraseological units that are characterized by a sign of constructive conditioning, compiled on the basis of the specifics of the language material selected for analysis and at our disposal. The obtained combined knowledge about the structural conditionality of phraseological units of the modern Russian language gives a complete image of this phenomenon.

\section{Conclusion}

Phraseology is the greatest treasury and the enduring value of any language. It, like a mirror, reflects the history and centuries-old experience of the labor and spiritual activities of the people and their moral values. Phraseology reflects the world of feelings, images, assessments of this or that people, it is most directly connected with the culture of speech production.

In addition, phraseology is an inexhaustible source of knowledge of the language as a developing and changing system. It contains both modern language formations and the most ancient language forms and constructions. Therefore, for those who are interested in the history and culture of the English people, phraseology is one of the most fascinating and entertaining areas of the language.

As for the phraseology of the English language, we can talk about its formation as a linguistic discipline, which is facilitated by a wide range of phraseological studies in the field of English. At present, the theoretical directions in phraseological studies that allow one to consider the available rich material in the light of such modern branches as discursive theory and cognitive science can be considered relevant. It seems necessary to apply a functional approach to studying the role of phraseological units in the communicative process, considering the principle of anthropocentrism.

Phraseology is still faced with completely unresolved problems. One of the pressing problems at this stage is the problem of phraseological significance, discussed by both domestic and foreign researchers in the field of phraseology. The semantic structure of phraseological units is complicated by the presence of a living WF, since the meaning of phraseological units correlates with both the literal meanings of lexemes and the meaning of the prototype. The fact that phraseological units form a certain system in a language that has its own laws indicates that they need to be studied in the light of the theory of language universals. This theory is a relatively new trend in modern linguistics. It should solve many issues related to phrase formation and identify those cognitive schemes for modeling idioms that are determined by both linguistic and extralinguistic factors. Pragmatics deals with the description of the facts of language in the aspect of human activity and the study of the behavior of signs in communication processes. The pragmatic function of phraseological units is realized in a particular context and consists of a targeted effect on the recipient.

This study focuses on the pragmatic potential of rethought terminological phraseological units, which are used to express the subject's emotional attitude to the subject of thought and to produce a specific, pragmatic effect on the recipient. 


\section{Bibliographic references}

ALEKHINA, A. I. 1982. Idiom of modern English. Minsk: Higher School, 279p.

ALEKSEEVA, L. M. 1998. Term and metaphor. Perm, 250 p.

AMOSOVA, H. H. 1965. On the diachronic analysis of phraseological units. In:

Studies in English phraseology. L.: Leningradskaja Univerzita., pp.101-107.

ARKHANGELSKY, V. L. 1964. Stable phrases in modern Russian. In: Rostov-onDon, pp.121-137.

ARNOLD, I. V. 1999. Semantics. The style. Intertextuality. SPb: SPbSU, 444p.

ARUTYUNOVA, N. D. 1990. Discourse. In: Linguistic Encyclopedic Dictionary. M.: Sov. Encyclopedia, pp. 136-137.

BABUSHKIN, A. P. 1996. Types of concepts in the lexical and phraseological semantics of the language. Voronezh: Voronezh State University. 104p.

BALLY, S. 2001. French style. In: Editorial URSS. 360p.

BLOOMFIELD, L. 1968. Language. In: Progress. 607p.

BUYANOVA, L. YU. - KOVALENKO, E.G. 2004. Russian phraseologism as a mental-cognitive means of linguistic conceptualization of the sphere of moral qualities of a person: Monograph. Krasnodar: KubSU. 166p.

CHERNYSHOVA, T.V. 1999. Usual-style complex as a mechanism for generating an invective statement in the field of newspaper journalism. In: Problems and Prospects: Interuniversity. Sat scientific tr. / Ed. N.D. Goleva. Barnaul.

KARASIK, V. I. 2000. On the types of discourse. In: Language personality: institutional and personal discourse: Sat. scientific labor. Volgograd: Change, pp. 520.

KOPYLENKO, M. M. - POPOVA, Z. D. 1989. Essays on general phraseology (Phrase combinations in the language system). Voronezh: Voronezh State University. 190p.

KUBRYAKOVA, E. S. 1997. Cognitive aspects of word formation and related rules of inference (semantic inference). In: New ways to study the word formation of Slavic languages. Magdeburg, pp. 29-39.

KUBRYAKOVA, E. S. 2000. On the concepts of discourse and discursive analysis in modern linguistics. In: Discourse, speech, speech activity: functional and structural aspects. RAS INION, pp.7-22.

KUNIN, A. B. 1984. The internal form of phraseological units. In: Word in grammar and dictionary. Nauka, pp. 183-188.

KABANOVA, E. V. 2011. Conceptualization of temperature in the German language picture of the world: Dis ... cand. filol. sciences. Barnaul. 244p.

LAKOFF, J. - JOHNSON, M. 1990. Metaphors with which we live. In: Theory of metaphor. M.: Progress, pp. 387-415.

LARIN, B. A. 1996. Essays on phraseology (On the systematization and research methods of phraseological materials). In: Modern Russian language: Lexicology. Lexicography: Reader and study assignments. SPb: SPbU, pp. 192-204.

MORRIS, C. W. 1971. Writings on the General Theory of Signs. The Hague: Mouton. (Contains Morris, 1938, Morris, 1946a, and other essays, as well as the first chapter of Morris, 1964.)

PASTUSHENKO, L. P. 1982. English phraseological units in the phraseo-thematic field (based on the phraseo-thematic field of marinisms): Dis ... cand. filol. sciences. Kiev. 194p.

POLIVANOV, E. D. 1991. Proceedings in Eastern and General Linguistics. Nauka. $624 \mathrm{p}$.

POPOVA, Z. D. - STERNIN, I. A. 2007. Basic features of a semantic-cognitive approach to language. In: Anthology of concepts. Gnosis.

XLinguae, Volume 13 Issue 2, April 2020, ISSN 1337-8384, ISSN 2453-711X 
SERIO, P. 1999. How to read texts in France. In: Squaring the meaning. French school of discourse. Progress, pp.12-53.

SEARLE, J. 1986. Basic concepts of the calculus of speech acts. In: New in foreign linguistics. Logical analysis of natural language. Vol. Xviii. Progress. pp.242-263.

SKLYAREVSKAYA, G. N. 1993. Metaphor in the language system. St. Petersburg: Nauka.152 p.

TELIA, V. N. 2004. Cultural strata in phraseological units and discursive practices. YaSK. 344 p.

TELIA, V. N. 1977. Secondary nomination and its types. In: Language nomination (Types of names). Nauka, pp. 129-221.

TELIA, V. N. 1986. The connotative aspect of the semantics of nominative units. Nauka. 143 p.

VEZHBITSKAYA, A. 1997. Prototypes and invariants. In: Language. The culture. Cognition. Rus. Dictionaries, pp.201-230.

VINOGRADOV, V. V. 1975. Questions of studying phrases (on the material of the Russian language): The main questions of the syntax of the sentence. In: Selected works: research on Russian grammar. Nauka, pp. 56-87.

ZHUKOVA, L. S. 2006. Concept LANGUAGE in the English national consciousness (based on the material of the modern British press). In: Conceptology: research experience: Sat. scientific tr / Novosib. state un-ty Novosibirsk, pp.70-75.

ZVEGINTSEV, V. A. 1976. Sentence and its relation to language and speech. In: Moscow State University. 307p.

Words: 4858

Characters: 32998 (18,33 standard pages)

professor Kalamkas Kalybayeva

Abay Kazakh National Pedagogical university

Dostyk ave 13, Almaty

Kazakhstan

associated professor Sagira Odanova

Kazakh State Women's Teacher Training Institute

Aiteke bi 99, Almaty

Kazakhstan

professor Altynai Tymbolova

Al Farabi Kazakh National university

Temiryazeva street 71, Almaty

Kazakhstan

professor Shattyk Erchozhina

Suleyman Demirel University

Ablay khan street 1/1, Kaskelen

Kazakhstan

Gulbagiza Musayeva

Al Farabi Kazakh National university

Temiryazeva street 71, Almaty

Kazakhstan

bislauka@mail.ru 